\title{
Electrodeposition and Corrosion Resistance of Ni-Graphene Composite Coatings
}

\author{
Benigna Szeptycka, Anna Gajewska-Midzialek, and Tomasz Babul
}

\author{
(Submitted November 13, 2015; in revised form February 18, 2016; published online March 23, 2016)
}

\begin{abstract}
The research on the graphene application for the electrodeposition of nickel composite coatings was conducted. The study assessed an important role of graphene in an increased corrosion resistance of these coatings. Watts-type nickel plating bath with low concentration of nickel ions, organic addition agents, and graphene as dispersed particles were used for deposition of the composite coatings nickel-graphene. The results of investigations of composite coatings nickel-graphene deposited from the bath containing $0.33,0.5$, and $1 \mathrm{~g} / \mathrm{dm}^{3}$ graphene and one surface-active substance were shown. The contents of particles in coatings, the surface morphology, the cross-sectional structures of the coated samples, and their thickness and the internal stresses were studied. Voltammetric method was used for examination of the corrosion resistance of samples of composite coatings in $0.5 \mathrm{M} \mathrm{NaCl}$. The obtained results suggest that the content of incorporated graphene particles increases with an increasing amount of graphene in plating bath. The application of organic compounds was advantageous because it caused compressive stresses in the deposited coatings. All of the nickel-graphene composite layers had better corrosion resistance than the nickel coating.
\end{abstract}

Keywords composites, corrosion and wear, metallic matrix, nanomaterials

\section{Introduction}

Advances in engineering and knowledge generate a need for new materials - including coatings with functional properties far superior to coatings habitually used in engineering. The intensive development of production techniques regarding a range of metal-matrix coatings featuring various dispersed phases - including electrochemical composite materials - is a result of this requisite.

Composite electrochemical coatings constitute a very promising and rapidly developing group of coatings generating a great interest, both in research work and in practical applications - particularly in the transportation, electrotechnical, food, and textile industries.

Composite electrochemical coating (CEC) deposition technologies provide opportunities to obtain coatings with unique properties. Most scientific publications concern $\mathrm{Ni}-\mathrm{Al}_{2} \mathrm{O}_{3}$ and $\mathrm{Cu}-\mathrm{Al}_{2} \mathrm{O}_{3}$ coatings.

Nickel is often used as a matrix to obtain electrochemical composite coatings. A nickel matrix is characterized by a great corrosion resistance in weakly acidic and alkaline environments including air, as well as by a considerable microhardness and

This article is an invited submission to JMEP selected from presentations at the Symposium "Metal-Matrix Composites," belonging to the topic "Composite and Hybrid Materials" at the European Congress and Exhibition on Advanced Materials and Processes (EUROMAT 2015), held September 20-24, 2015, in Warsaw, Poland, and has been expanded from the original presentation.

Benigna Szeptycka, Anna Gajewska-Midzialek, and Tomasz Babul, Institute of Precision Mechanics, 3 Duchnicka Street, 01-796 Warsaw, Poland. Contact e-mail: gajewska@imp.edu.pl. good tribological properties. Certain nickel coating properties may be improved by incorporating a dispersed phase.

A nickel coating's increase of corrosion resistance may be achieved by the incorporation of dispersions like $\mathrm{Cr}_{2} \mathrm{O}_{3}$ (Ref 1 ), $\mathrm{SiC}$ (Ref 2-4), BN (Ref 5), $\mathrm{Al}_{2} \mathrm{O}_{3}$ (Ref 4, 6), $\mathrm{CeO}_{2}$, and $\mathrm{ZrO}_{2}$ stabilized with $\mathrm{CeO}_{2}$ (Ref 7).

Composite coatings containing PTFE (Ref 8,9$)$ as well as hybrid coatings (Ref 10,11) also display a corrosion resistance superior to a nickel coating.

The use of these coatings allows to boost significantly anticorrosive and tribological properties of materials like steel, aluminum, copper, and brass. At the same time, their production technique reveals technical and economic indicators superior to those of other production techniques of coatings with similar functional properties, i.e., CVD, PVD, or metal spraying.

Graphene - a new material discovered in 2004 by Geim et al. (Ref 12)-finds an increasing number of applications (Ref 13-15).

Single carbon atom layers in a hexagonal lattice formed by graphene allow for numerous potential applications. Among others, its properties include a very large specific surface, a very good heat and electrical conductivity, a high electron mobility in ambient temperature, and a great resistance to stretching.

The superior properties of graphene as lubricating agent in rotational friction was demonstrated by Berman et al. (Ref 16). A graphene film deposited on a steel surface with an $1 \mathrm{~g} / \mathrm{dm}^{3}$ ethanol solution and subjected to a Balltester (Kulotester) trial at $30 \%$ humidity resulted in a sixfold reduction of steel wear and a sixfold reduction of the friction coefficient under testing conditions. Electrolytic nickel-graphene coatings demonstrate good microwave absorbance qualities (Ref 17) and soft magnetic properties.

Wang et al. (Ref 18) electrodeposited a nickel-graphene coating, producing earlier the graphene oxide from graphite with a modified Hummers method (Ref 19, 20) and reducing the graphene oxide during the electrodeposition of nickel. A composite coating thus produced featured good catalytic 
properties during an urea oxidation reaction in a $1 \mathrm{M} \mathrm{KOH}$ solution. Such a catalyst can be potentially used in the production of hydrogen and in fuel cells.

Nickel-graphene composite coatings were deposited from a sulfamate electrolyte by Kuang et al. (Ref 21) using graphene oxide (GO) reduced to graphene under electrodeposition conditions. Graphene content in the nickel coating was $0.12 \%$ weight. These particles constrained a change in the nickel crystallographic matrix orientation from (200) to (111). The composite coating thus created had a greater hardness and better heat conductivity than a nickel coating.

Another path was chosen by Kumar et al. (Ref 22). They reduced with hydrazine a graphene oxide obtained by exfoliation, then they deposited the composite coating from a very diluted electrolyte containing nickel and sodium sulfates as well as boric acid. The coating thus created had a greater hardness and corrosion resistance than a nickel coating. Graphene particles changed the orientation of the nickel matrix from (220) to (200) and caused a reduction of this matrix' grains from 30 to $20 \mathrm{~nm}$. The refinement of the matrix grain and the incorporation of graphene particles within resulted in an increase of the coating's microhardness by $100 \mathrm{HV}$. The corrosion rate of the composite coating was two and half times smaller than the corrosion rate of a nickel coating.

The graphene is a new material revealing a set of properties that does not occur in any other material. Leading industries in Europe have shown serious interest in graphene, including the fields of mobile telecommunications and cars production. We undertook studies on the production of composite coatings with graphene to verify to what extent such coatings could replace known and currently used composite coatings in such applications as corrosion resistance increase, or tribological wear reduction. In the submitted article, we present the first study regarding such coatings' resistance to corrosion. The results of wear resistance are given in work Szeptycka at al. (Ref 23)

\section{Experimental Part}

\subsection{Electrodeposition Process}

The electrodeposition of $\mathrm{Ni}$ and Ni-graphene coatings was carried out using a substrate of $85 \times 65 \times 1 \mathrm{~mm}$ copper sheets and a nickel bath with a composition as provided in Table 1. The quantity of boric acid used in the bath ensures that a correct $\mathrm{pH}$ shall be maintained over a long period of time. The anode was a nickel sheet with a surface twice as large. The substrate was prepared in the following manner:

- Degreasing with Vienna lime and etching with 1:1 hydrochloric acid (for corrosion resistance and roughness testing).

- Passivation with a $10 \%$ solution of sodium chromate (VII)

Table 1 Composition of the nickel bath

\begin{tabular}{ll}
\hline Component & \multicolumn{1}{c}{ Connection } \\
\hline $\mathrm{NiSO}_{4} \cdot 7 \mathrm{H}_{2} \mathrm{O}$ & $0.45 \mathrm{M}$ \\
$\mathrm{NiCl}_{2} \cdot 6 \mathrm{H}_{2} \mathrm{O}$ & $0.30 \mathrm{M}$ \\
$\mathrm{H}_{3} \mathrm{BO}_{3}$ & $0.85 \mathrm{M}$ \\
Graphene iGP2 & $0.33 ; 0.5 ; 1 \mathrm{~g} / \mathrm{dm}^{3}$ \\
\hline
\end{tabular}

to permit the removal of deposited coating (for particle content testing).

Dispersion particles used were Grafen-iGP2 by Grafen Chemical Industries Co., with a diameter of $5 \mu \mathrm{m}$, a thickness of 5-8 nm, and a specific surface of $120-150 \mathrm{~m}^{2} / \mathrm{g}$ (www. grafen.com.tr).

The bath was prepared with reactants "pure for analytical purposes" and distilled water, oxidized and pre-electrolyzed to remove impurities, then supplemented with a dispersion of particles and additional components.

The GRN additive was used as the anti-pitting and leveler component.

To produce the graphene dispersion, an anionic high fluorinated surfactant (SPA) by Aldrich was used.

Composite coatings and the nickel coating were deposited at a $\mathrm{pH} 4$, in a temperature of $318 \mathrm{~K}$ and with a current density of $4 \mathrm{~A} / \mathrm{dm}^{2}$ during $30 \mathrm{~min}$ using a magnetic stirrer with a rotational speed of $100 \mathrm{rev} / \mathrm{min}$.

\subsection{Coating Characteristic}

The dispersion particles' content in the composite coating were assayed by titration.

Thickness control of produced layers was performed by making cross sections on Struers devices. Etched metallographic samples were observed under a Nikon Eclipse JV 150 optical microscope.

The images of deposited coatings' surfaces were recorded using a metallographic microscope.

Sample surface images were realized with a scanning adapter and a JEM 100C transmission electron microscope. An analysis of the chemical composition on the surface of the samples' surface was carried out with an ISIS 300 energy dispersion $\mathrm{x}$-ray spectrometer at a $40 \mathrm{kV}$ acceleration voltage.

Internal stresses were measured using the dilatometric method (Ref 16) with an IS-meter by OMI International, Austria. Internal stress was expressed in MPa using a simplified formula:

$\sigma=-\frac{E_{0} \cdot t_{0} \cdot \lambda}{2 l_{0} \cdot t}$

where $\sigma$ is the internal stress in coating, (MPa); $\lambda$ is the change of sample length, $(\mathrm{mm}) ; l_{0}$ is the length of coating in sample, $(\mathrm{mm}) ; t_{0}$ is the thickness of base metal, $(\mathrm{mm}) ; E_{0}$ is the elastic modulus of substrate, $(199.3 \mathrm{GPa})$; and $t$ is the coating thickness ( $\mathrm{mm})$.

Nickel and composite coatings were deposited on an Armco iron substrate measuring $250 \times 10 \times 0.09 \mathrm{~mm}$. The overlay length of the nickel coating was $160 \mathrm{~mm}$.

\subsection{Electrochemical Corrosion Resistance Characteristics}

Corrosion resistance was measured using the voltametric method with a three-electrode system. The reference electrode was chloride-silver electrode, the auxiliary electrode was platinum electrode. The working surface of the electrode subjected to corrosion testing was $1 \mathrm{~cm}^{2}$. The test temperature was $20 \pm 2{ }^{\circ} \mathrm{C}$. The basic element of the measurement setup was a computer-controlled Atlas 98 potentiostat by Sollich. Data control, collection, graphic, and quantitative analysis were performed with POL-99 software. Potential variation speed was $1 \mathrm{mV} / \mathrm{s}$. Testing was carried out in a $0.5 \mathrm{M}$ non-deoxygenated 


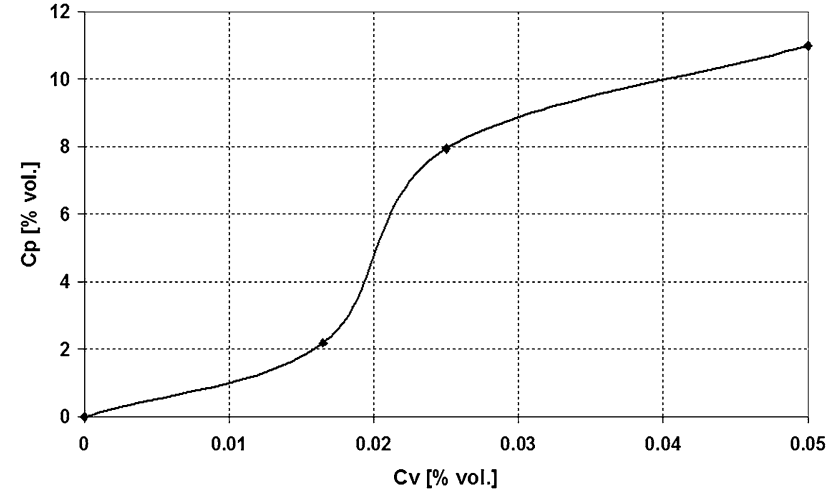

Fig. 1 The change of incorporated graphene particles' content depending on the change of their content in the bath (vol.\%)

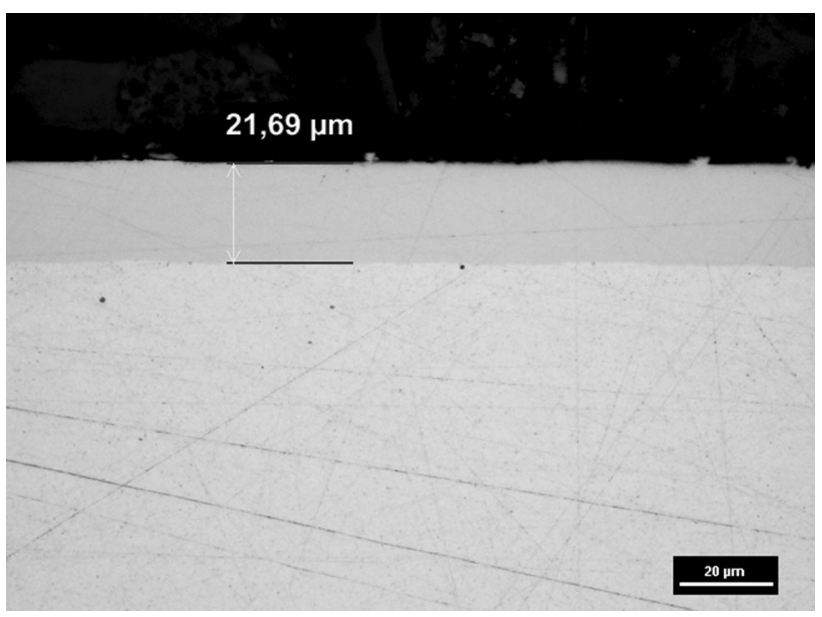

Fig. 2 Cross section of Ni-graphene composite coating. Sample 1. Magnification $\times 500$

sodium chloride solution with a $\mathrm{pH}$ 7. The $i=f(E)$ curves were recorded within a range of $\pm 0.3 \mathrm{~V}$ of the stationary potential. The obtained Tafel curves were used to calculate the corrosion current and potential, and corrosion rate.

The percentage reduction of the corrosion rate $P$ is defined as

$P=\frac{r_{\mathrm{kor}, 0}-r_{\mathrm{kor}}}{r_{\mathrm{kor}, 0}} 100[\%]$,

where $r_{\text {kor }, 0}$ - nickel coating corrosion rate (mm/year); $r_{\text {kor }}$ composite coating corrosion rate (mm/year).

\section{Results and Discussion}

Figure 1 represents the change of incorporated graphene particles' content depending on the change of their content in the bath.

Cross-section photograph of obtained Ni-graphene composite coatings is presented in Fig. 2.

Figure 3 represents a photograph of this surface realized with a metallographic microscope.

Figure 4 represents a SEM image of a Ni-graphene coating and Fig. 5 and 6 represent EDS spectra from two sample locations.

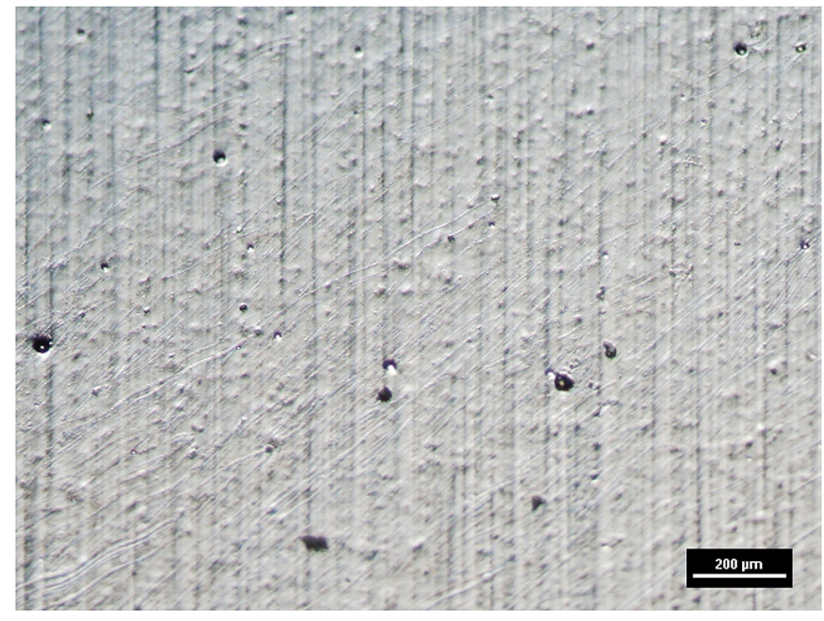

Fig. 3 Image of a Ni-graphene composite coating deposited on a copper substrate. Sample 1. Metallographic microscope. Magnification $\times 50$

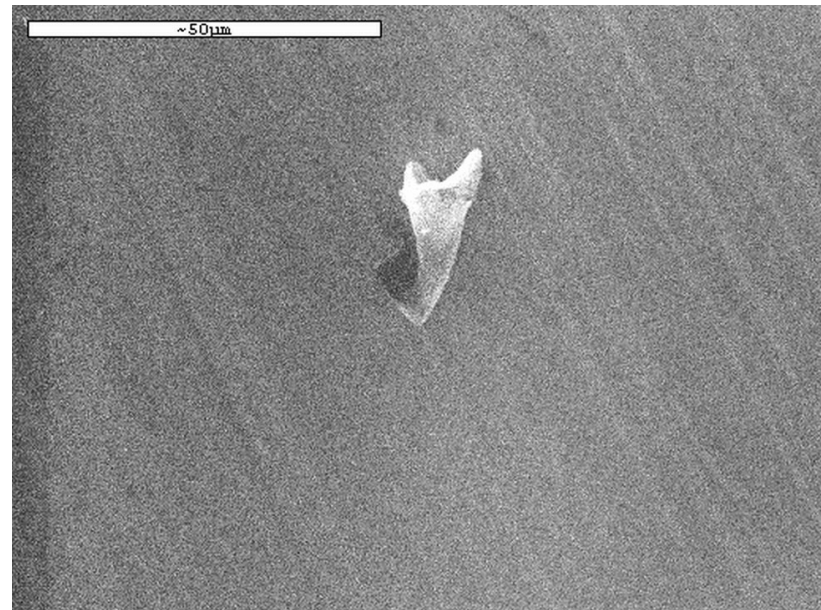

Fig. 4 SEM image of a Ni-graphene coating. Sample 3. Graphene particle in nickel coating

Figure 7 shows resulting relations between internal stress and the thickness of Ni-graphene composite coatings deposited from a nickel bath in the presence of surfactant SPA with regard to three levels of concentration of graphene $0.33,0.5$ and $1 \mathrm{~g} / \mathrm{dm}^{3}$. In addition, Fig. 4 shows this relationship in regard to a coating deposited from a low concentration bath with additive GRN.

Table 2 is a compilation of sample numbers, potential and corrosion current, corrosion rate, and the percentage reduction of the corrosion rate in a $0.5 \mathrm{M} \mathrm{NaCl}$. For a nickel coating deposited from a low concentration bath with GRN, the density of the corrosion current in $0.5 \mathrm{M} \mathrm{NaCl}$ was $0.85 \mu \mathrm{A} / \mathrm{cm}^{2}$, the corrosion potential $-233 \mathrm{mV}$ and the corrosion rate $10.45 \times 10^{-3} \mathrm{~mm} /$ year.

Polarization curves of composite coatings Ni-G in $0.5 \mathrm{M}$ $\mathrm{NaCl}$ are shown in Fig. 8.

\section{Discussion of Results}

During the deposition of Nickel-graphene composite coatings with the electrochemical reduction method were used iGP2 graphene particles in an amount of $0.33,0.5$, and $1 \mathrm{~g} / \mathrm{dm}^{3}$ in a 
dispersion with a surfactant. The results of the measurements regarding the content of graphene particles incorporated in the composite coating (Fig. 1) revealed that in particular deposition conditions it is possible to incorporate these particles within a range of 2 to $10 \%$ of volume.

The thickness of deposited nickel-graphene coatings was about $20 \mu \mathrm{m}$ (Fig. 2) and they differed slightly one from another. The attached photograph of the surface realized with a metallographic microscope reveals graphene inclusions in the nickel matrix (Fig. 3). EDS spectra (Fig. 5 and 6) of the nickel coating and the particle visible in Fig. 4 confirmed the presence of graphene in composite coatings. The size of the crystallites in nickel coating was $20.4 \mathrm{~nm}$.

Tests were performed regarding the impact of content of graphene particles incorporating in the composite coating on the internal stress in these coatings. The internal stress in the $\mathrm{Ni}$ graphene composite coatings was compressive in the entire analyzed thickness range and it varied from -445 to $-104 \mathrm{MPa}$ (Fig. 7). Stress stabilization of deposited coatings started from a thickness of about $10 \mu \mathrm{m}$. For a thickness of $30 \mu \mathrm{m}$ and in respect to a graphene content of, respectively, $0.5,1.9$, and $2.7 \%$ weight, the obtained internal stress values were, respectively, $-156,-104$, and $-126 \mathrm{MPa}$. These results confirm earlier

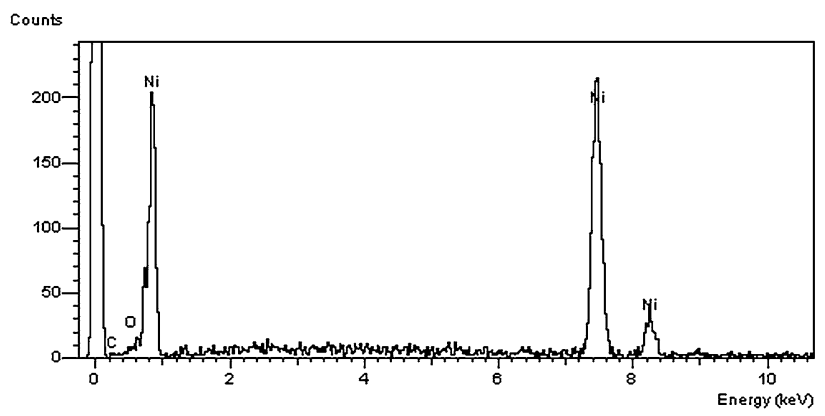

Fig. 5 EDS spectrum of smooth coating surface in Fig. 4

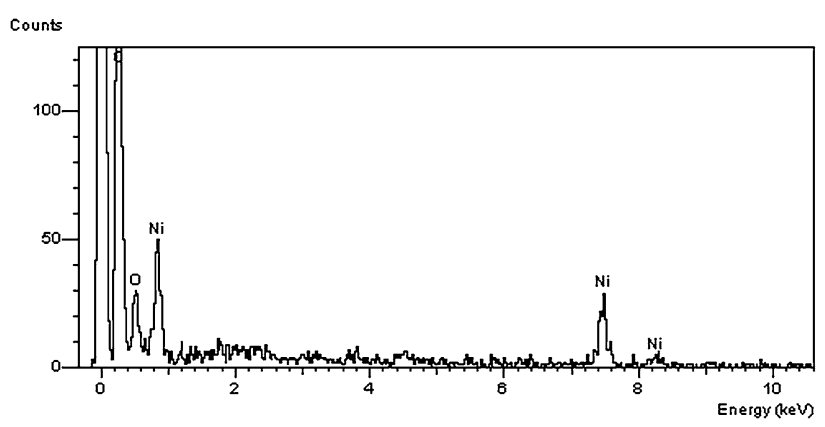

Fig. 6 EDS spectrum of graphene particle in Fig. 4
Szeptycka's findings (Ref 24), that an increase of the content of incorporated dispersive particles has an impact on the reduction of the size of nickel matrix crystallites and, consequently, the deposition of coatings featuring compressive stress.

The corrosion rate diminished as the dispersed phase content in the composite coating increased. The greatest corrosion resistance in a $0.5 \mathrm{M} \mathrm{NaCl}$ solution was displayed by a coating deposited from a bath with a $1 \mathrm{~g} / \mathrm{dm}^{3}$ graphene content. This coating's corrosion rate was seven times slower than in the case of a nickel coating without these additives, while the percentage reduction of the corrosion rate in respect to a nickel coating was $85.84 \%$. The corrosion rate was also slower than the corrosion rate of a Ni-G coating analyzed by Kumar et al. (Ref 22). Both the cathodic and anodic current density of these coatings were smaller than the current density for a nickel coating (Fig. 8), as well as a corrosion potential shift toward positive. The presented study is the beginning of an extensive investigation

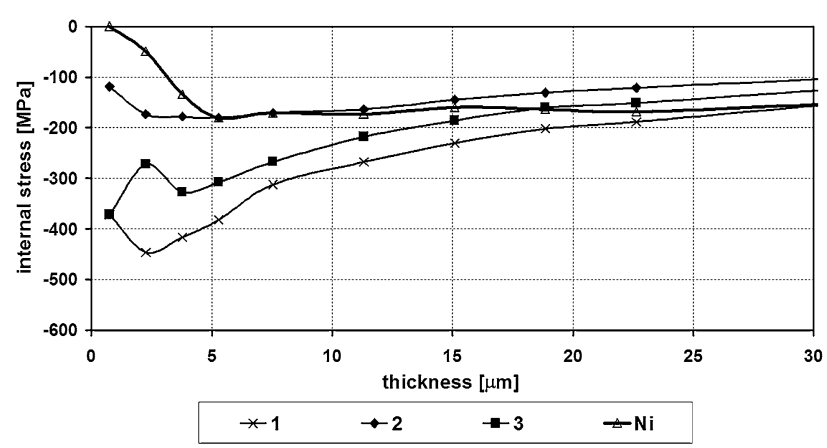

Fig. 7 Internal stress of the Ni-graphene coatings deposited from the bath containing GRN, graphene, and SPA surfactant

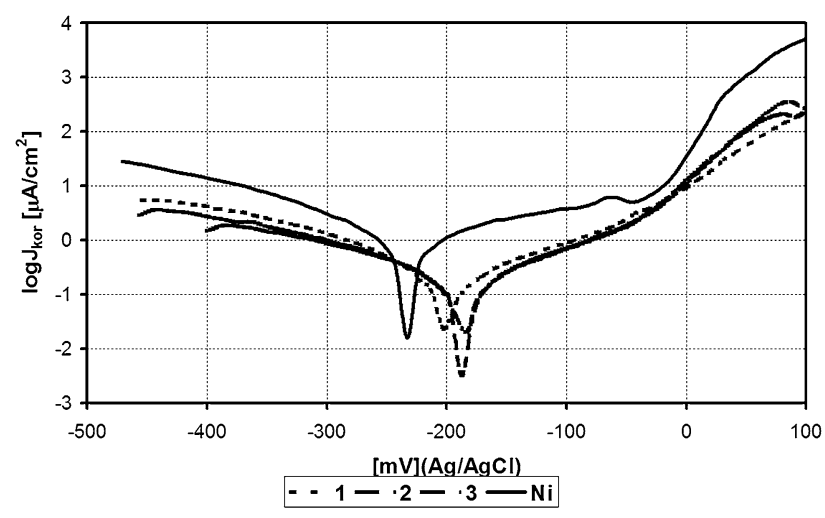

Fig. 8 Polarization curves in $0.5 \mathrm{M} \mathrm{NaCl}$. Ni-G composite coatings deposited from a bath with the addition of graphene, GRN, and SPC. For comparison of nickel coating without graphene

Table 2 Sample numbers, measurement results of potential and corrosion current, corrosion rate, and the percentage reduction of the corrosion rate in $0.5 \mathrm{M} \mathrm{NaCl}$

\begin{tabular}{lcccc}
\hline $\begin{array}{l}\text { Sample } \\
\text { no. }\end{array}$ & $\begin{array}{c}\text { Corrosion } \\
\text { potential } \boldsymbol{E}_{\mathbf{K o r}}, \mathbf{V}\end{array}$ & $\begin{array}{c}\text { Corrosion current } \\
\text { density } \boldsymbol{J}_{\mathbf{K o r}} \boldsymbol{\mu} \mathbf{A} / \mathbf{c m}^{\mathbf{2}}\end{array}$ & $\begin{array}{c}\text { Corrosion rate } \\
\boldsymbol{r}_{\mathbf{i}} \times \mathbf{1 0}^{\mathbf{- 3}}, \mathbf{m m} / \mathbf{y e a r}\end{array}$ & $\begin{array}{c}\text { Percentage reduction } \\
\text { of the corrosion rate } \mathbf{P}, \boldsymbol{\%}\end{array}$ \\
\hline $\mathrm{Ni}$ & -233 & 0.85 & 10.45 & $\ldots$ \\
1 & -202 & 0.17 & 2.04 & 80.48 \\
2 & -186 & 0.14 & 1.78 & 82.97 \\
3 & -188 & 0.12 & 1.48 & 85.84 \\
\hline
\end{tabular}


in this domain. An increase of corrosion resistance can be explained by a reduction of metallic surface accessible to the corrosive environment.

A too restrained research scope (the cost of graphene being too high) did not provide an opportunity to verify the dependence between the corrosion rate and the content of incorporated dispersive particles; however, despite this reduced scope, the research results are consistent with the results obtained by Szeptycka (Ref 25), namely that the incorporated dispersive particles initially decrease the corrosion rate owing to a reduction of the metallic surface exposed to a corrosive environment.

\section{Summary}

It has been demonstrated that it is possible to incorporate iGP2 graphene particles in a nickel matrix using the electrochemical reduction method. The presence of graphene in nickel-graphene composite coatings has been validated with the EDS analysis method.

All analyzed nickel-graphene composite coatings featured compressive internal stresses and a better corrosion resistance than a nickel coating.

\section{Open Access}

This article is distributed under the terms of the Creative Commons Attribution 4.0 International License (http://creative commons.org/licenses/by/4.0/), which permits unrestricted use, distribution, and reproduction in any medium, provided you give appropriate credit to the original author(s) and the source, provide a link to the Creative Commons license, and indicate if changes were made.

\section{References}

1. T.Y. Cupak, N.N. Waleev, V.N. Dahov, and I.N. Andreev, Wlijanie technologii elektroosazdenia pokryti nikielem nikiel- $\mathrm{Cr}_{2} \mathrm{O}_{3}$ na ich zaszczitnyje swojstwa (Influence of Electrodeposition Technology of Nickel Coatings Nickel- $\mathrm{Cr}_{2} \mathrm{O}_{3}$ on Their Achieved Properties), Zashchita Metallov, 1987, 4, p 684-686

2. L. Benea, A. Bonora, A. Borello, and S. Martelli, Effect of SiC Size Dimensions on the Corrosion Wear Resistance of the Electrodeposited Composite Coating, Mat. Corr., 2002, 53, p 23-29

3. C.F. Malfatti, J. Zopas Ferreira, C.B. Santos, B.V. Souza, E.P. Fallavena, S. Vaillant, and J.-P. Bonino, NiP/SiC Composite Coatings: The Effects of Particles on the Electrochemical Behavior, Corr. Sci., 2005, 47, p 567-580

4. M. Gladkovas, V. Medeliene, M. Samuleviciene, and E. Juzeliunas, Corrosion Study of Electroplated Nickel-Matrix Composites with $\mathrm{B}_{4} \mathrm{C}$, $\mathrm{Al}_{2} \mathrm{O}_{3}$ and $\mathrm{SiC}$, Chemija, 2002, 13(1), p 36-40

5. G.N.K. Ramesh Bapu, Characteristics of Ni-BN Electrocomposites, Plat. And Surf. Finish., 1995, 6, p 70-73
6. B. Szczygieł and M. Kołodziej, Corrosion Resistance of $\mathrm{Ni} / \mathrm{Al}_{2} \mathrm{O}_{3}$ Coatings in $\mathrm{NaCl}$ Solution, Trans. Inst. Metal Finish., 2005, 83(4), p 181-187

7. S. Balathandan and S.K. Seshadri, Polarization Behavior of NickelBased Electrocomposites, Metal Finish., 1994, 92(2), p 49-53

8. B. Szeptycka, A. Gajewska-Midziałek, and D. Derewnicka, Ivestigations of the Resistance of Corrosion of Nanostructural Composite Coatings Ni-PTFE, Phys. Chem. Mech. Mater. Spec. Issue, 2004, 4, p 608-612

9. B. Szeptycka and A. Gajewska-Midziałek, The Influence of the Structure of the Nanocomposite Ni-PTFE Coatings on the Corrosion Properties, Rev. Adv. Mater. Sci., 2007, 14, p 135-140

10. B. Szeptycka and D. Derewnicka, Preparation and Characterisation of d.c.-Plated Nanocrystalline Nickel Deposits, Acta Phys. Pol., A, 2002, 102(2), p 199-205

11. B. Szeptycka and A. Gajewska-Midziałek, Investigation of the Electrochemical Corrosion Resistance of Hybrid Ni-SiC-Fluoropolymer Composite Coatings, Mater. Manuf. Process., 2005, 20, p 23-34

12. K.S. Novoselov, A.K. Geim, S.V. Morozov, D. Jiang, Y. Zhang, S.V. Dubonos, I.V. Grigorieva, and A.A. Firsov, Electric field Effect in Automatically Thin Carbon Films, Science, 2004, 306, p 666-669

13. S. Gilje, S. Han, M. Wang, K.L. Wang, and R.B. Kaner, A Chemical Route to Graphene for Device Applications, Nano Lett., 2007, 7, p 3394-3398

14. M.J. Allen, V.C. Tung, and R.B. Kaner, Honeycomb Carbon: A Review of Graphene, Chem. Rev., 2010, 110, p 132-145

15. V. Singh, D. Joung, L. Zhai, S. Das, S.I. Khondaker, and S. Seal, Graphene Based Materials: Past, Present and Future, Prog. Mater Sci., 2011, 56, p 1178-1271

16. D. Berman, A. Erdemir, and A.V. Sumant, Few Layer Graphene to Reduce Wear and Friction on Sliding Steel Surfaces, Carbon, 2013, 54, p 454-459

17. J. Fang, W. Zha, M. Kang, S. Lu, L. Cui, and S. Li, Microwave Absorption Response of Nickel/Graphene Nanocomposites Prepared by Electrodeposition, J. Mater. Sci., 2013, 48, p 8060-8067

18. D. Wang, W. Yan, S.H. Vijapur, and G.G. Botte, Electrochemically Reduced Graphene Oxide-Nickel Nanocomposites For Urea Electrolysis, Electrochim. Acta, 2013, 89, p 732-736

19. W.S. Hummers, Jr, and R.E. Offeman, Preparation of Graphitic Oxide, J. Am. Chem. Soc. , 1958, 80, p 1339-1339

20. D. Wang, Y. Hasin, P. Li, and Y. Wu, Preparation, Characterization, and Electrocatalytic Performance of Graphene-Methylene Blue Thin Films, Nano Research, 2011, 4, p 124-130

21. D. Kuang, L. Xu, L. Liu, W. Hu, and Y. Wu, Graphene-Nickel Composites, Appl. Surf. Sci., 2013, 273, p 484-490

22. P.C.M. Kumar, T.V. Venkatesha, and R. Shabadi, Preparation and Corrosion Behavior of Ni and Ni-Graphene Composite Coatings, Mat. Res. Bull., 2013, 48, p 1477-1483

23. B. Szeptycka and A. Gajewska-Midzialek, Nickel-Graphene Composite Coatings, Compos. Theory Pract., 2015, 2, p 107-111

24. B. Szeptycka, Naprężenia własne galwanicznych powłok niklowych. Część 2. Wpływ cząstek dyspersyjnych i związków organicznych na naprężenia własne kompozytowych powłok niklowych (The Internal Stresses of the Galvanic Nickel Coatings. Part 2. Influence of the Dispersion Particles and the Organic Compounds on the Internal Stresses of the Composite Nickel Coatings), Inżynieria Powierzchni, 2009, 1, p 46-53

25. B. Szeptycka, Kształtowanie struktury $i$ wlaściwości elektrolitycznych nanowarstw kompozytowych Ni-SiC, Ni-PTFE i Ni-SiC-PTFE (Formation the Structure and Properties of Electrolytic Composite Nanocoatings Ni-SiC Ni-PTFE i Ni-SiC-PTFE), Institute of Precision Mechanics, Warsaw, 2009 